\title{
Fatigue and Physical Performance in Recreational Sports
}

\author{
$1^{\text {st }}$ Dian Listiarini \\ Graduates school of sports science \\ sports science faculty, yogyakarta state \\ university \\ Yogyakarta, Indonesia \\ dianlistiarini.2019@student.uny.ac.id \\ $4^{\text {th }}$ Didit Prakosa Adi Nugroho \\ Department of Sport Science \\ sports science faculty, semarang state \\ university \\ Semarang, Indonesia \\ diditg660@gmail.com
}

\author{
$2^{\text {nd }}$ BM. Wara Kushartanti \\ Department of Sport Science \\ sports science faculty, yogyakarta state \\ university \\ Yogyakarta, Indonesia \\ bm_warakushartanti@uny.ac.id \\ $5^{\text {th }}$ Setya Rahayu, \\ Department of Sport Science \\ sports science faculty, semarang state \\ university \\ Semarang, Indonesia \\ setyarahayu@mail.unnes.ac.id
}

\author{
$3^{\text {rd }}$ Mohammad Arif Ali \\ Department of Sport Science \\ sports science faculty, semarang state \\ university \\ Semarang, Indonesia \\ hiarifalikhan@mail.unnes.ac.id \\ $6^{\text {th }}$ Natsuangkorn Kongchulagul \\ Department of Physical Education \\ Faculty of Education, Kasetsart \\ University \\ Thailand \\ natsuangkorn.ko@ised.tu.ac.th
}

\begin{abstract}
Every physical activity must cause fatigue because it involves the body's moving components, one of the biological signs of this fatigue can be seen from the accumulation of blood lactate in the body. Hiking, rafting, and jogging are recreational sports. Each type of sport has its own training needs following the movements performed and exercises in recreational sports are carried out to avoid the risk of injury that can occur. The level of fatigue and injury in hiking, rafting, and jogging shows different graphs. To achieve certain achievements one must train harder. While recreational sports only need to practice to master the movements to be performed and avoid the risk of injury. Both types of exercise provide the same effect, namely fatigue. There is no specific sign of fatigue that occurs in recreational sports because training for achievement sports and recreation is not much different
\end{abstract}

Keywords - fatigue, recreational sports, blood lactate.

\section{INTRODUCTION}

Physical activity that involves the body's activating components including bones, soft tissues (muscles, tendons, ligaments) must be done properly and correctly so as not to cause interference or injury [1]. In sports, fatigue is a deterioration in the body's function and results in suboptimal appearance or movement [2]. If fatigue is not handled properly, fatigue can result in muscle trauma or mild category of muscle strain, such as Delayed Onset Muscle Soreness (DOMS), but DOMS is also a physiological response arising from new training adaptations, [3], [4].

Performance improvement must pay attention to the part of the body that will be trained, especially biomotor, especially skeletal muscles because muscles are elastic body tissues that can change shape when we move the body. Muscles will change lengthwise and shorten according to the movement of the exercise we are doing [5]. Modification of the volume of exercise can stimulate the body's adaptation on an ongoing basis, this method is also called the concept of progressive overload [6]. As for some physical components that can be trained to improve performance, namely: cardiorespiratory endurance, muscular endurance, muscular strength, body composition, flexibility [7]. Physical improvement training must also pay attention to the principles of exercise including frequency, intensity, type, time [8].

Many people in this world do physical activity sports. Sports itself is divided into 2 types namely achievement sports and recreation. As the name implies, sporting achievement require physical training to achieve achievement, while recreational sports have the same goal but are more intended as a means to improve physical fitness, [9]. When doing physical activity sports will certainly cause fatigue because the body moves and motion in the body requires energy. Exhaustion that occurs causes a buildup of metabolic waste in the body called blood lactate, this metabolic waste must be minimized so as not to cause the effects of excessive fatigue, [10]. Reducing blood lactate stacks and accelerating recovery due to exercise fatigue can use several therapies, one of which is intended using foam rolling therapy, [11]

The purpose of this review is to find out whether there are similarities in physical performance requirements between recreational sports and achievement sports and whether there are differences in indicators of fatigue between recreational sports.

\section{METHOD}

Materials, this is a narrative review, data in this paper are secondary. Mainly original studies within last ten years of being published were considered on this paper, additionally other references were being used only to support the storylines in order to answer the research objectives. Materials were obtained from data stations such as Google Scholar, PubMed, ResearchGate, Reports, Blogspots, News Paper, etc.

Methods, there are three stages must be done sequentially in order to provide acceptable answers for the questions. 1) The Codifying or Compilation Stage is when investigators doing collection and sorting all related materials from sources. 2) Analysis and Synthesis Stage, profound and detailed examination (extracting data) on how data from chosen materials could be constructed into data interpretation. 3) 
Conclusion Drawing is the last stage to end the process of literature study and to state the novelty of study.

\section{RESULT AND DISCUSION}

\section{A. Hiking and fatigue}

It is a physical activity carried out outdoors (outdoor) or can be called nature-based recreational sports. Hiking can also be regarded as nature tourism, of course, this activity needs a lot of preparation for physical strengthening training and natural knowledge because there are many things that must be learned from nature. Although there is a term of tourism, the sport of hiking also needs exercise because it will be very draining physically and dangerous when doing hiking experiencing physical disorders [12]. Some important things that need to be considered before hiking are hiking protocols, ethics, walking techniques, hiking equipment (food, personal needs, medicines and, first aid kit), safety when hiking and, procedures in emergency situations [13].

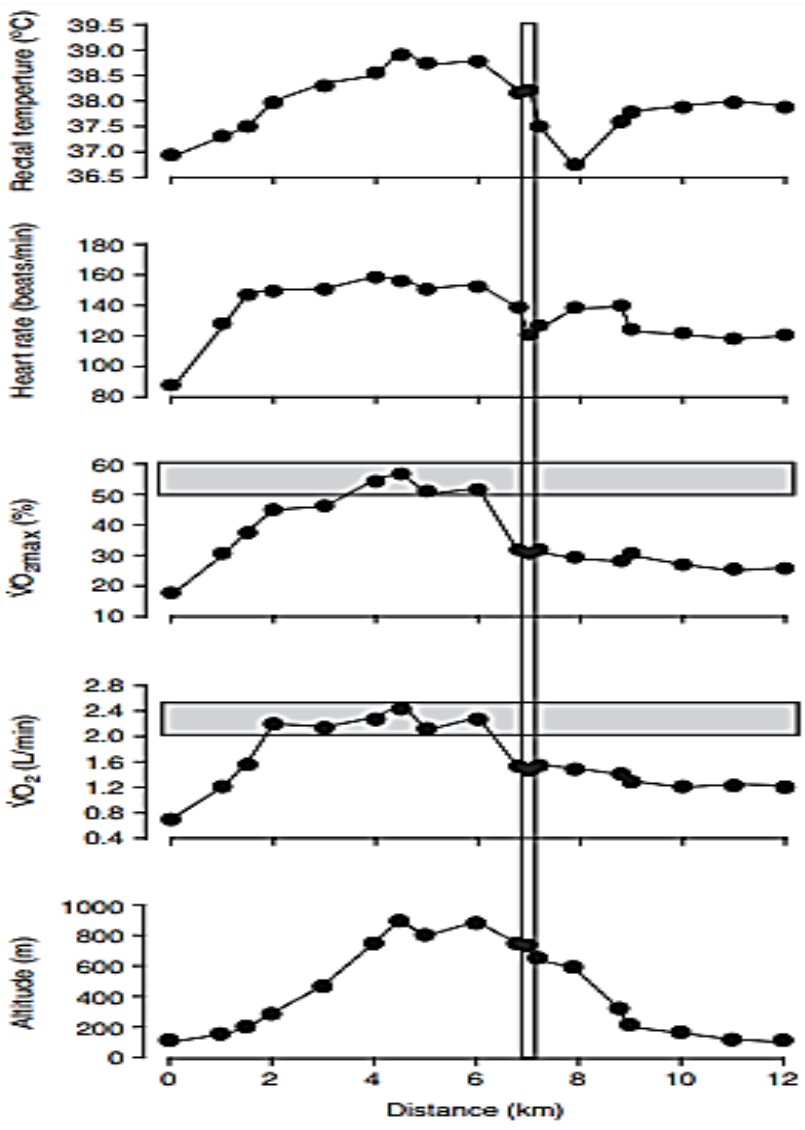

Graph 1 [15].

In the picture graph, 1 shows the mechanism of fatigue when hiking. Includes data on oxygen consumption (VO2), heart rate, and body temperature. The vertical line is when the climber is stopped or resting for 30 minutes while the horizontal line is when the climber is experiencing fatigue and starts to lack of oxygen.

Endurance is very important when climbing because this activity tends to require quite a long time if the distance that must be passed to reach the top of the climb reaches thousands of meters above sea level. Hiking or hiking has the potential to cause fatigue and physiological responses to the body because it requires muscles to work for long periods of time [14]. Climbing is very potential to cause pressure on the body system when walking outdoors with bad weather causes physiological disorders. Fatigue during climbing is very dangerous because it will cause hypothermia. The beginning of hypothermia is when the movement begins to decrease followed by body temperature also decreases in weather conditions that tend to be bad. Walking away produces lactate in the blood and triggers fatigue, this fatigue will lead to an emergency or dangerous situation. If hypothermia occurs there will be advanced symptoms such as lack of oxygen and decreased heart rate, [15].

\section{B. Rafting and fatigue}

Rafting is a sport that contains an element of tourism and can also be called a recreational sport. Rafting is a water walk or river rafting activity using facilities such as rubber boats, kayaks, canoes, and rowing. To be able to enjoy this sport it also requires practice, which is to often navigate the river and paddle in order to be able to control the direction of the rubber boat while in the river current. Therefore good and optimal physical performance is very necessary because it is also useful as accident prevention when rafting [16].

\begin{tabular}{|c|c|c|c|}
\hline Training Program & $\begin{array}{c}\text { Number } \\
\text { of } \\
\text { Sessions } \\
\text { (n) }\end{array}$ & $\begin{array}{l}\text { Lactate } \\
(\mathrm{mmol} / \mathrm{l})\end{array}$ & $\begin{array}{l}\text { Heart Rate } \\
\text { (per min) }\end{array}$ \\
\hline Moderate Long Distance (ModLDT) & 236 & $1.47+/-0.65$ & $146.5+/-15.1$ \\
\hline Medium Long Distance (MedLDT) & 39 & $2.47+/-0.88$ & $163.6+/-9.2$ \\
\hline Long Distance Training with 15 strokes & 12 & $3.04+/-0.76$ & $163.1+/-9.4$ \\
\hline $\begin{array}{l}\text { Power (endurance) Training(PT) including } \\
80-120 \text { strokes }\end{array}$ & 36 & $3.64+/-0.96$ & $171.5+/-10.0$ \\
\hline $\begin{array}{l}\text { Intensive Long Distance Training(IntLDT: } \\
15-20 \mathrm{~min} \text { ) }\end{array}$ & 16 & $3.66+/-1.28$ & $168.8+/-7.8$ \\
\hline $\begin{array}{l}\text { Intensive Long Distance Training(IntLDT: } \\
10 \mathrm{~min} \text { ) }\end{array}$ & 46 & $4.48+/-1.73$ & $172.7+/-8.8$ \\
\hline $\begin{array}{l}\text { Pyramid(e.g., 30-40-50-60-50-40-30 } \\
\text { strokes) }\end{array}$ & 28 & $5.95+/-1.33$ & $175.5+/-12.6$ \\
\hline $5 \mathrm{kmin}$ Short Time (with heart rate) & 9 & $5.88+/-1.75$ & $165.0+/-11.1$ \\
\hline $5 \mathrm{~km}$ in Short Time (without heart rate) & 20 & $6.87+/-2.03$ & \\
\hline $10 \mathrm{~km}$ in Short Time & 25 & $6.23+/-1.67$ & \\
\hline Altemate Training, $3 \times 7 \mathrm{~min}$ & 32 & $6.84+/-1.49$ & $184.1+/-10.6$ \\
\hline Altemate Training, $3 \times 4 \mathrm{~min}$ & 26 & $8.52+/-2.00$ & $183.8+/-12.9$ \\
\hline Altemate Training, $3 \times 7$ and $3 \times 4 \mathrm{~min}$ & 48 & $7.59+/-1.92$ & $184.0+/-11.6$ \\
\hline Altemate Training, 2 or $3 \times 2 \mathrm{~min}$ & 10 & $10.74+/-1.17$ & \\
\hline $\begin{array}{l}2000 \mathrm{~m} \text { Temp Training, } 6 \text { strokes }<\text { race } \\
\text { frequency }\end{array}$ & 17 & $7.27+/-2.02$ & $177.8+/-13.0$ \\
\hline $\begin{array}{l}1500 \mathrm{~m} \text { Tempo Training, } 3 \text { strokes } \sim \text { race } \\
\text { frequency }\end{array}$ & 16 & $10.57+/-2.48$ & $178.8+/-7.6$ \\
\hline $500 \mathrm{~m}$ Tempo Training & 158 & $9.88+/-2.17$ & \\
\hline 1000m Tempo Training & 83 & $12.48+/-2.61$ & \\
\hline $1500 \mathrm{~m}$ Tempo Training & 14 & $12.90+/-2.08$ & \\
\hline Test Regatta -Dursburg & 45 & $13.75+/-2.59$ & \\
\hline Intemational Regatta-Luceme & 38 & $15.24+/-3.30$ & \\
\hline
\end{tabular}

Table 1 shows the level of blood lactate buildup and the rate of increase in heart rate when doing rowing exercises, seen from the amount of each exercise with increasing intensity of the exercise also increases blood lactate which causes fatigue when rowing [17]. When performing the mechanism of rowing the body parts that work include hands, shoulders, back, chest, hips, and knees. [18]. Rafting moves the body almost entirely 
in every part of the body, the core of the rafting movement is rowing. Rowing movements that involve many parts of the muscles and joints certainly require training to be optimal in doing rafting and reduce the risk of injury or accidents due to fatigue while exercising.

\section{Jogging and fatigue}

The phenomenon that occurs in the field of many people from all ages ranging from children, adolescents, adults to elderly people like to do this sport on weekends. Jogging is a running sport but with a low speed that can be done outside the room (field) or indoors using a tool (treadmill) [19]. Any physical activity related to exercise in sports will cause fatigue [20]. Movement when jogging involves all parts of the body, every movement of exercise or, while exercising there will definitely be a dominant body part working. Jogging or running at low speed is more dominant using the lower limb body from the hips to the toes [21]. Although it is called recreational sports, jogging also affects the body's physiology and has many benefits. An athlete and non-athlete will do exercises to just maintain fitness or to improve physical performance. Physical fitness is most easily obtained by doing jogging, therefore jogging is included in sports increasing the physical performance of muscular endurance and is more dominant in cardiorespiratory [22]. Besides jogging can also be used as an activity for recovery after strenuous sports or matches. Fatigue after strenuous exercise or higher intensity than usual causes accumulation of lactate in the blood, [23]. Graph 2 below shows wiped lactate production when running or jogging.

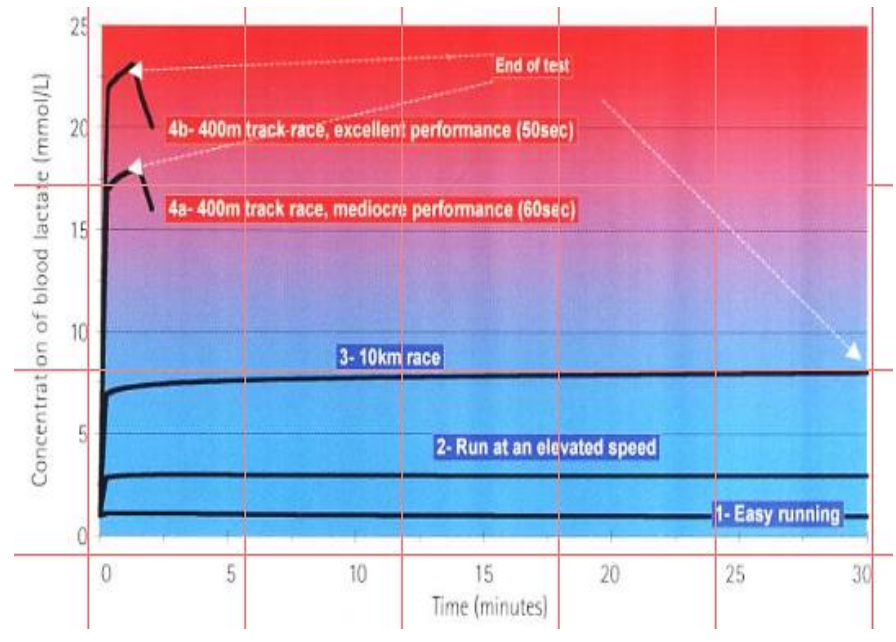

Graph 2 [24]

\section{CONCLUSION}

Recreational sports are activities that are popular with many people, there are similarities and slight differences between recreational sports and achievements, namely recreational sports also require skills, endurance, and strength, but with a smaller amount when compared to achievement sports. To achieve certain achievements one must train harder even to experience excessive fatigue due to new exercises or exercises with increased intensity, in addition to training as a target of training is also used to overcome the risk of injury when competing. While recreational sports only need to practice to master the type of sport that will be done and avoid the risk of injury that can occur. Both types of exercise provide the same effect, namely fatigue. Looking at the data available for each sports activity the exercise needs and the level of exhaustion varies. There is no specific sign of fatigue that occurs in recreational sports because basically training for achievement sports and recreation is not much different.

\section{REFERENCES}

[1] M. A. Elmagd, "Benefits, need and importance of daily exercise," Int. J. Phys. Educ. Sport. Heal., vol. 3, no. 5, pp. 22-27, 2016.

[2] A. Dal Monte, M. Faina, and G. Mirri, "Fatigue and sport," Funct. Neurol., vol. 17, no. 1, pp. 7-10, 2002.

[3] A. Setiawan, "Faktor Timbulnya Cedera Olahraga," Media Ilmu Keolahragaan Indones., vol. 1, no. 1, 2011.

[4] A. Ilmawan, "Pengaruh Delayed Onset of Muscle Soreness Massage Terhadap Penurunan Nyeri Dan Peningkatan RangeOf Motion Serta Fungsi Pada Kasus Delayed Onset of Muscle Soreness Pada Tungkai,' Universitas Negeri Yogyakarta, 2018.

[5] C. Sifa, "Strength Training ( Latihan Kekuatan ) Oleh : Faizal Chan , Porkes Fkip Universitas Jambi menempuh parameter dan alur periodisasi Adapun dalam periodesasi latihan strength terdiri : 1 . Fase Adaptasi Anatomi 3 . fase conversion 5 . Fase transition Fase pe," no. 1, pp. 1-8, 2012.

[6] R. Ramírez-Campillo et al., "Effect of Progressive Volume-Based Overload during Plyometric Training on Explosive and Endurance Performance in Young Soccer Players,” J. Strength Cond. Res., vol. 29, no. 7, pp. 1884-1893, 2015, doi: 10.1519/JSC.0000000000000836.

[7] K. Singh, "a Study of Physicalactivity, Exercise, and Physical Fitness: Definitions and Bifurcation for Physical Related Research.," Acad. Sport. Sch., vol. II, no. III, pp. 1-5, 2013, doi: 10.9780/22773665/1112013/37

[8] Hadafi Fitri, A. H. Omar, and A. Syahrom, "the Effectiveness of Fitt Principle in Exercise Rehabilitation Focusing on Common Sports Injuries Among Malaysian Athletes," no. January 2014, pp. 1-1, 2014, doi: 10.15282/mohe.2014.res.034.

[9] P. Modak, "Sports and recreational activities : an overview of Students ' Perception and Awareness," vol. 53, no. 45, 2015.

[10] M. Gleeson, A. K. Blannin, N. P. Walsh, C. N. E. Field, and J. C. Pritchard, "Effect of exercise-induced muscle damage on the blood lactate response to incremental exercise in humans," Eur. J. Appl. Physiol. Occup. Physiol., vol. 77, no. 3, pp. 292-295, 1998, doi: 10.1007/s004210050336.

[11] S. W. Cheatham, M. J. Kolber, M. Cain, and M. Lee, "the Effects of Self-Myofascial Release Using a Foam Roll or Roller Massager on Joint Range of Motion, Muscle Recovery, and Performance: a Systematic Review.," Int. J. Sports Phys. Ther., vol. 10, no. 6, pp. 827-38, 2015.

[12] P. Chhetri, C. Arrowsmith, and M. Jackson, "Determining hiking experiences in nature-based tourist destinations," Tour. Manag., vol. 25, no. 1, pp. 31-43, 2004, doi: 10.1016/S0261-5177(03)00057-8.

[13] M. Naude, Contents Section 1: Hiking Protocol , Etiquette and Technique. CAPE NATURE, 2012.

[14] M. F. Vieira, I. S. De Avelar, M. S. Silva, V. Soares, and P. H. L. Da Costa, "Effects of four days hiking on postural control," PLoS One, vol. 10, no. 4, pp. 1-19, 2015, doi: 10.1371/journal.pone.0123214.

[15] P. N. Ainslie, I. T. Campbell, J. P. Lambert, D. P. M. Maclaren, and T. Reilly, "<Ainslie 2005 Physiological and metabolic aspects of very prolon.pdf>," vol. 35, no. 7, pp. 619-647, 2005.

[16] Nastain, "Standarisasi Sarana Dan Prasarana Objek Wisata Arung Jeram Rainbow Rafting Di Desa Kecepit, Kecamatan Randudongkal, Kabupaten Pemalang,” Pendidik Jasm. Kesehat. Dan Rekreasi Fak. Ilmu Keolahragaan Univ. Negeri Semarang, 2016.

[17] U. Hartmann, a Mader, and W. Hollmann, "Heart rate and lactate during endurance training programs in rowing and its relation to the duration of exercise by top elite rowers," FISA Coach, no. 11, pp. 121-141, 1990 
[18] M. S. Rokhade, S. T. Chavan, and A. M. Chakradeo, "Design and Manufacturing of Mechanism for Rowing Simulator," no. March, 2019.

[19] J. A. García-Pérez, P. Pérez-Soriano, S. Llana Belloch, Á. G. LucasCuevas, and D. Sánchez-Zuriaga, "Effects of treadmill running and fatigue on impact acceleration in distance running," Sport. Biomech., vol. 13, no. 3, pp. 259-266, 2014, doi: 10.1080/14763141.2014.909527.

[20] B. Belza, "The Impact of Fatigue on Exercise Performance," pp. 176180, 1994.

[21] J. Liebenberg, J. Scharf, D. Forrest, J. S. Dufek, K. Masumoto, and A. Mercer, "Determination of muscle activity during running at reduced body weight," no. October 2014, pp. 37-41, 2011, doi: 10.1080/02640414.2010.534806
[22] M. Buchheit, P. M. Lepretre, A. L. Behaegel, G. P. Millet, G. Cuvelier, and S. Ahmaidi, "Cardiorespiratory responses during running and sportspecific exercises in handball players," J. Sci. Med. Sport, vol. 12, no. 3, pp. 399-405, 2009, doi: 10.1016/j.jsams.2007.11.007.

[23] I. MARZUKI HARAHAP and F. Rohman Kafrawi, "Pengaruh Pemulihan Aktif (Jogging) Terhadap Penurunan Kadar Asam Laktat Dalam Darah Setelah Latiahan Anaerobik (Interval Training)," J. Kesehat. Olahraga, vol. 5, no. 2, pp. 43-50, 2016.

[24] H. Hernawati, "Produksi Asam Laktat Pada Exercise Aerobik Dan Anaerobik," Fpmipa Upi, pp. 1-2, 2013 